\title{
Batı Felsefesinde Hayvanın Ahlâkî Statüsü: Francione'nin Abolisyonizmi Üzerine Bir Değerlendirme
}

DOI: 10.26466/opus.720047

\section{Hakan Olgun *}

* Dr. Öğr. Üyesi, Bilecik Şeyh Edebali Üniversitesi/Ï̈BF, Bilecik/Türkiye E-Posta: hakan.olgun@bilecik.edu.tr

ORCID: 0000-0002-8650-0211

Öz

Hayvanın ahlâkî statüsüne ilişkin çağdaş tartışmanın en önde gelen üç ismi Peter Singer, Tom Regan ve Gary L. Francione'dir. Singer 'hayvan özgürleşmesi' davasının 'hayvanların acı çekmemekteki menfaatlerinin eşit biçimde gözetilmesi' yoluyla kazanılabileceğini iddia ederken, Regan ahlâkî topluluğun sınırlarının belirlenmesinde 'bir hayatın öznesi olma' vasfinın dikkate alınması gerektiğini ileri sürer. Bu tarz fikirlerin belki de en radikal örneklerinden birini sunan Francione ise hayvanların yegâne kurtuluş yolunun onların mülk statülerinin sona erdirilmesinden ve her türlü hayvan kullanımının terk edilmesinden geçtiğ̈ini iddia eden 'abolisyonist' yaklaşımın başlıca temsilcisidir. Francione bir yandan Singer gibi hazzı ve acıyı hissetme kabiliyetinin ahlâkî statü için gerekli yegâne kriter olduğunu ileri sürerken, diğer yandan da Regan gibi, hayvanların içkin bir ahlâkî değer taşıdıkları fikrine sahiptir. Ancak zihnî gelişmişlik düzeyinin ahlâkî statü değerlendirmelerinde hiçbir yerinin olmaması gerektiğini söyleyen Francione, ahlâkî hiyerarşilerin tümden reddini içeren deontolojik bir pozisyonun savunuculuğunu yapar. Dolayısıyla Francione'nin bazı açılardan Singer ve Regan'dan ayrıldı̆̆ını ve onlardan daha radikal bir tavır aldığını söylemek mümkündür. Dahası Francione'ye göre çağdaş 'hayvan haklar hareketi'nin yürüttüğ̈̈ strateji, 'haklar' nosyonunu temel almaması ve dolayısılyla reformcu olması sebebiyle külliyen yanlıştır. Ona göre izlenmesi gereken en uygun strateji, reformcu kampanyalardan uzak durmak ve veganizmi merkezine alan eğitim programları aracilğ̆zyla hayvan ürünlerine olan talebi azaltmaktır.

Anahtar Kelimeler: Hayvan refahı, Hayvan hakları, Abolisyonizm, Gary L. Francione 


\title{
The Moral Status of the Animal in the Western Philosophy: An Assessment on Francione's Abolitionism
}

\begin{abstract}
The three most important names in the contemporary debate on the animal's moral status are Peter Singer, Tom Regan and Gary L. Francione. While Singer noted that the case for 'animal liberation' could be acquired 'through equal consideration of the interests of animals not to suffer', Regan suggested that 'being a subject of a life' should be taken into account in determining the boundaries of the moral community. Presenting one of the most radical examples of such ideas, Francione is the main representative of the 'abolitionist' approach claiming the only way to save animals is through the termination of their property status and the abandonment of all forms of animal use. Similar to the argument of Singer, Francione has stated that the ability to feel pleasure and pain is the sole criterion for moral status, and he thinks that animals have an inherent moral value parallel to the idea of Regan. However, noting that the mental development level should have no place in moral status assessments, Francione advocates a deontological position that includes unequivocal rejection of moral hierarchies. Thus, it is possible to state that Francione dissented from Singer and Regan at some points but adopted a more radical attitude. Moreover, according to Francione, the strategy conducted by the contemporary 'animal rights movement' is completely wrong because it is not based on the notion of 'rights' and is therefore reformist. According to him, the most appropriate strategy to adopt is to stay away from the reformist campaigns and decrease the demand for animal products through educational programs focusing on veganism.
\end{abstract}

Keywords: Animal welfare, Animal rights, Abolitionism, Gary L. Francione 


\section{Giriş}

"Atların veya sığırların, elleri ve çizim yapma kabiliyetleri olsaydı" der, antik filozoflardan Xenophanes, "atlar tanriları at sûretinde, sığırlar da sığır sûretinde resmederlerdi”. Öyleyse eski Yunanlar'ın kendi tanrılarını insan sûretinde tasvir etmiş olmaları, varlıklar düzeninde insana tanıdıkları aslî ve merkezî konumun açık bir işareti olsa gerektir. İnsanlık durumunu 'ulûhiyet' ile 'hayvanlar âlemi' arasında bir yere konumlandıran Batı felsefesi, dünyevî varlıklar arasında tanrılara en yakın olma şerefini insana bahşetmiştir. Bu yakınlığın en tabiî neticesi, insanın cümle mahlûkat üzerinde efendilik yapma ruhsatını elde etmiş olmasıdır. Oysa tanrılara ilişkin tasvirlerden şüphe etmek, bu imtiyazlı statüye meydan okumak anlamına gelir; böylece insan, kendisine ve hayvanlara dair kanaatlerini gözden geçirmek zorunda kalır. Xenophanes örneği, Batı felsefesinde insana ve hayvana dair eski kavramların sınırlarını göstermekte; hayvan doğasına ilişkin tecrübeleri lâyıkıyla aksettirecek yeni kavramlara duyulan ihtiyacı dile getirmektedir (Steiner, 2005, s. 1). İşte bu ihtiyaç yahut insan-hayvan ilişkilerinin nasıl bir ahlâkî çerçeveye oturtulması gerektiği meselesi Batı felsefesinin en kadim tartışma konularından biri olagelmiştir.

Ne var ki bu tartışmanın tarihî süreçte genellikle hayvanların aleyhine sonuçlandığı aşikârdır. Sözgelimi Eski Yunan dünyası her şeyin ölçüsü olarak insanı almış, Hristiyanlığın Eski Ahit'ten tevarüs ettiği yaratılış öyküsü hayvanları açıkça insanın istifadesine sunmuş, Aydınlanma düşüncesi daha da ileri giderek hayvanların acıyı hissetme kabiliyetinden yoksun birer makineden ibaret olduğunu iddia edebilmiştir. Elbette bu süreç hayvanlar lehine ileri sürülen birtakım heretik fikirlere de sahne olmuştur. Fakat son kertede hayvan, içkin bir ahlâkî değer taşımayan ve insanın amaçları uğruna sınırsızca suistimal edilebilecek bir nesne olarak telakki edilmiş; hayvana karşı doğrudan bir ahlâkî yükümlülük taşıma fikri kabul görmemiştir. Hayvanların, genellikle insanlara hasredilen muhakeme yeteneği, dil kullanma becerisi, benlik bilinci veya ahlâkî fâillik gibi birtakım kabiliyet ve vasıflardan mahrum oldukları düşüncesi, onların ahlâkî cemaate dâhil olmalarının önünde aşılmaz bir engel teşkil etmiştir.

19. yüzyıl, bilhassa 'faydacı' filozofların tesiriyle, hayvanlara dair anlayışın değişmeye başladığı bir zaman dilimi oldu. Bu dönemin âmentüsü sayılabilecek 'insanî muamele prensibi', hayvanların hissetme kabiliyetine sahip 
varlıklar olarak en azından acı çekmemekte menfaatleri olduğunu teslim ediyordu. Böylece hayvanlara yönelik doğrudan bir ahlâkî yükümlülük getiriyor; onlara lüzumsuz eziyet edilmesini yasaklıyordu. Dahası bu yeni anlayış salt ahlâkî bir prensip olarak kalmadı; o dönemde ABD ve İngiltere'de, sonraları diğer pek çok ülkede çıkarılan zulüm karşıtı yasalarda da ifadesini buldu. Bütün bu gelişmeler bugünün dünyasında yaygın olarak kabul edilen ve bu tarz yasalara ilham veren 'hayvan refahı' anlayışının temelini oluşturmaktadir.

Gelgelelim hayvanların lehine gibi görünen bu gelişmeler hayvan ızdırabını dindirmekte ve meseleye ilişkin tartışmaları sonlandırmakta yetersiz kalmıştır. Bu başarısızlığın sebebini, 'hayvan refahı' anlayışında mündemiç olan 'lüzumsuz eziyet etmeme' prensibinde aramak gerekir. Zira 'lüzumsuz eziyet' kavramının mefhum-1 muhalifinden, eziyet içeren bazı muamelelerin pekâlâ 'lüzumlu' olduğu kanaatine varmak mümkündür. Uygulamada da böyle olmuş; bu tarz bir muameleden insanın elde ettiği menfaat hayvanın çektiği ızdıraptan büyükse, eziyetin lüzumlu olduğu sonucuna varılmıştır. Böyle bir değerlendirmenin manipülasyona ve keyfîliğe ne denli açık olduğuna hiç şüphe yoktur. Gerçekten de insanın menfaati ile hayvanın menfaatinin ihtilâfa düştüğü hemen her durumda ilki galebe çalmış, bu gerekçeyle hayvanlara reva görülen zâlimâne muameleler hayli geniş bir repertuvar oluşturmuştur. Meselâ bir köpeği sırf eğlence maksadıyla elektrik şokuna maruz bırakmak hukukî müeyyide gerektiren gayriahlâkî bir davranış iken, aynı muameleyi insana fayda sağlayacağı düşünülen bir deney kapsamında yapmak, hukukî veya ahlâkî bakımdan meşrû kabul edilmiştir. Hayvanların sistematik bir biçimde istismar edildiği fabrika tarzı çiftlikler, tıbbî araştırma laboratuvarları, kürk endüstrisi, sirkler, hayvanat bahçeleri ve benzerleri, faaliyetlerinin büyük bir kısmını bu tarz bir meşrûlaştırma üzerine inşa etmişlerdir.

Hayvan refahı anlayışının ancak kısmî bir başarı sağlayabilmiş olması, 1970'li yıllardan itibaren derin bir felsefî tartışmanın önünü açtı. Tartışmaya öncülük eden düşünürler, hayvanların, insanlara hasredilen zihnî yetilerden mahrum oldukları gerekçesiyle ahlâkî topluluktan dışlanması fikrini reddettiler. Onlara göre, meselâ bazı zihnî yetilere sahip olan insansı maymunlar dahi ahlâkî topluluk dişında tutulurken, bundan yoksun olan bebeklerin veya demanslı hastaların dışlanmıyor olmaları, hattâ bunların acı verici de- 
neylerde kullanılmaları fikrinin bile dehşet verici bulunması, mevcut kabullerin sergilediği tutarsızlığın bariz bir göstergesiydi. Ahlâkî sınır çizilirken sergilenen bu keyfî yaklaşımı 'türcülük' olarak adlandıran düşünürlere göre, ahlâkî dairenin sınırları hayvanları da kapsayacak biçimde genişletilmeliydi. Bahsi geçen düşünürler bu doğrultuda birbirinden farklı bir dizi çözüm reçetesi sundular. Sözgelimi Peter Singer 'hayvan özgürleşmesi' davasının 'menfaatlerin eşit biçimde gözetilmesi' yoluyla kazanılabileceğini iddia ederken, Tom Regan, ahlâkî topluluğun sınırlarının belirlenmesinde 'bir hayatın öznesi olma' vasfının dikkate alınması gerektiğini ileri sürdü.

Bu tarz fikirlerin en radikal örneklerinden birini ise Gary L. Francione sunmaktadır. Francione; hayvanların yegâne kurtuluş yolunun, onların mülk statülerinin sona erdirilmesinden ve her türlü hayvan kullanımının terk edilmesinden geçtiğini iddia eden 'abolisyonist' yaklaşımın başlıca temsilcilerindendir. İşte bu yazı esasen Francione'nin 'abolisyonist' fikirlerini ve bu fikirler üzerinde cereyan eden tartışmaları konu edinmektedir. Yazıda önce, esas konuya temel oluşturmak üzere, 'hayvan refahı' anlayışı ile 'hayvan hakları' yaklaşımı arasında süregelen ve hayvan hareketinde derin bir yarılmayı temsil eden tartısmaya yer verilmiştir. Ardından yukarıda zikredilen iki önemli ismin; Singer ve Regan'ın fikirlerine değinilmiştir. Bu fikirler, Francione' nin hayvan hareketindeki pozisyonunun nereye tekâbül ettiğinin anlaşılması bakımından önemlidir. Bunu müteakiben Francione' nin 'abolisyonist' yaklaşımı ele alınmış, yazının son kısmı ise bu yaklaşıma yönelik tenkitlere ayrılmıştır.

\section{Hayvan Davasında Bir Fay Hattı: 'Hayvan Refahı' versus ‘Hayvan Hakları'}

AMP (Americans for Medical Progress/Tıbbî İerleme Yanlısı Amerikalılar); tıbbî araştırmaların hastalıkların tedavisindeki rolü konusunda halkı, medyayı ve siyasetçileri bilinçlendirme misyonu taşıyan, yönetim kurulu üyelerini ilahiyatçların, eğitimcilerin, siyasetçilerin, iş adamlarının ve hukukçuların oluşturduğu hayırsever bir cemiyettir. AMP'nin 1994 yılında ülkedeki hukuk fakültelerinin dekanlarına gönderdiği ilginç mektup, bu fakültelerde müfredatın bir parçası olarak ortaya çıkan tehlikeli bir akıma; 'hayvan hakları felsefesi'ne dikkat çekiyordu. AMP'ye göre hayvanların da insanlar gibi haklara sahip olduklarını iddia eden bu tuhaf felsefe, bereket ki ülkede ancak çok kü- 
çük bir azınlığın desteğini sağlayabilmişti. Mektupta halkın kahir ekseriyetinin 'hayvan refahı' anlayışını desteklediği ileri sürülüyor, hukuk fakültelerinde 'hayvan hakları' adı altında okutulan zararlı fikirlerin, sağlık hizmetleriyle ilgilenen herkes için bir uyarı mâhiyetinde olduğu ifade ediliyordu. AMP'ye göre bu fikirler doğrultusunda yürütülen bazı radikal faaliyetlerin biyomedikal araştırmaları sekteye uğratma riski vardı. Gereken tedbir alınmazsa, Amerikalılar'ın tedavi için bekledikleri süreler uzayacak ve sağlık hizmetleri için katlanmak zorunda oldukları maliyet artacaktı (Francione, 1996a, s.28).

Yukarıdaki paragraf, hayvanın ahlâkî statüsü etrafında dönen felsefî tartışmanın seyrinin, birbirine muhalif iki yaklaşım tarafından belirlendiğini açıkça ortaya koyar. Bu yaklaşımlardan ilki 'hayvan refahı', diğeri ise 'hayvan hakları'dır. 'Hayvan refahı' yaklaşımı, hayvanların acıyı ve hazzı hissetme kabiliyetine sahip varlıklar olduğu anlayışına dayanır. Hayvanlar bu kabiliyetleri sebebiyle bir nebze ahlâkî değer taşırlar ve bu durum onlara karşı dolaysız bir ahlâkî yükümlülük doğurur. 'İnsanî muamele' olarak anılan bu yükümlülük, anlamını 'lüzumsuz eziyet etmeme' prensibinde bulmaktadır (Garner, 2008, s.111). Dolayısıyla 'hayvan refahı' yaklaşımı, insanî muamelede bulunulduğu sürece, yani lüzumsuz eziyet etmemek şartıyla, hayvanların insanın menfaati için kullanılmasına ya da öldürülmesine cevaz verir (Ünder, 1996, s.166). Başka bir deyişle hayvana yapılan muameleden elde edilen toplam fayda, hayvanın maruz kaldığı acıya ağır basıyorsa, hayvanların gıda, giyim, araştırma veya eğlence gibi amaçlar için kullanılmasında ahlâken bir sakınca yoktur (Regan, 1998, s.42). Bu yaklaşımın günümüz dünyasında gördüğü yaygın kabul sebebiyle âdeta ahlâkî bir nas hâline geldiğini (Garner, 2008, s.111) söylemek mümkündür. Nitekim dünyanın pek çok ülkesinde yürürlükte bulunan 'zulüm karşıtı' yasalar, meşrûiyetini bu yaklaşımdan almaktadir.

'Hayvan refahı' yaklaşımının temeli, 'faydacı' ahlâk felsefesinin mimarlarından Jeremy Bentham'a (1748-1832) dayanır. Bentham'a göre herhangi bir eylemin ahlâkî bakımdan doğruluğu veya yanlışlığı, o eylemin sonuçlarından hareketle tespit edilir. Öyleyse ahlâken en doğru eylem, sonuçları itibariyle en fazla sayıda insana azamî ölçüde haz sağlayan eylemdir (Arslan, 2016, s.150). Buna ilişkin değerlendirme; 1rk, cinsiyet, zekâ düzeyi veya fizikî kabiliyet gibi hususlardan bağımsız olarak, bütün tarafların hazzının eşit bir biçimde gözetilmesini gerektirir (Francione, 2010a, s. 7). Çünkü bir kimsenin 
eşit gözetilmesini sağlayan yegâne vasıf, acıyı ve hazzı hissetme kabiliyetidir. Bentham bu ahlâkî eşitlik prensibini "herkes bir sayılmalı; hiç kimse birden fazla sayılmamalı" biçiminde formüle etmiştir (Singer, 2005, s. 42-45). Bentham'ın o dönemde cârî olan kölelik kurumuna karşı çıkışı da işte bu prensip dolayısıyladır. Zira kölelik kurumu esasen ırk ayrımına dayanıyor; siyahların acı ve ızdırabı karşısında beyazların haz ve mutluluğuna ağırlık tanıyarak eşitlik prensibini ihlâl ediyordu. Bentham daha da ileri giderek, bu prensibin 'türleri' de görmezden gelmesi gerektiğini ileri sürdü. Şayet ahlâkî topluluğa dâhil olmak için acı ve haz duyma kabiliyeti yeterli ise, eşitlik prensibi hayvanları da ihâta edecek biçimde genişletilmeliydi (Singer, 1996, s. 8). Bentham (2017, s. 143-144) bu gerekliliği açık bir biçimde şöyle dile getiriyordu:

Belki bir gün hayvanların geri kalanı da, zorbalık yoluyla mahrum birakıldıklarn haklarına tekrar kavuşacaklardır. Fransızlar, bir insanın, sırf siyah derisi sebebiyle bir zalimin keyfine terk edilemeyeceğini idrak ettiler. Belki günün birinde bacak sayısının, derideki tüy miktarının veya kuyruk sokumunun nerede sonlandığının, duygulu bir varlı̆̆ı aymı kadere terk etmek için eşit ölçüde yetersiz mazeretler olduğu da teslim edilecektir. Bu aşılmaz sınırı başka ne çizebilir? Muhakeme kabiliyeti mi? Yoksa konuşma melekesi mi? Lâkin yetişkin bir at veya köpek; bir günlük, bir haftalı, hattâ bir aylık bir bebekle knyaslanamayacak kadar akull ve sosyal bir hayvandır. Ama velev ki aksi olsun, bu neyi gösterir? Sorulmasi gereken soru; "Muhakeme edebiliyorlar mı?" veya "Konuşabiliyorlar mı?" değil, "Acı çekebiliyorlar mı?" olmalıdır.

Bentham'ın hayvanlara lüzumsuz eziyet etmemek gibi dolaysız bir yükümlülük içeren bu yaklaşımının, hayvanın ahlâkî statüsüne ilişkin mülâhazalarda önemli bir dönüşüme sebep olduğu muhakkaktır (Francione, 2008a, s. 247). Lâkin Bentham, kölelik kurumu karşısındaki muhalefetinin bir benzerini, hayvanların insanlar tarafından kullanılması karşısında sergilememiştir. Zira Bentham'a göre hayvanların, acı ve ızdırapları asgarî seviyeye çekildiği müddetçe, insanın amaçları doğrultusunda kullanılmalarının ve hattâ öldürülmelerinin ahlâken bir mahzuru yoktu. Bentham'a böyle düşündüren husus, insan ve hayvan zihni arasında vârolduğuna inandığı keyfiyet farkıydı. Buna göre hayvanlar yalnızca şimdiki zamanda yaşıyorlar, öldürüldüklerinde neyi kaybettiklerinin farkına varmıyorlardı (Francione, 2010a, s. 9). Ölümün hayvana verdiği zararın insana verdiği zarardan daha az olduğunu söyleyen Bentham'a göre, hayvanların acı çekmemekte çıkarları olmakla birlikte, hayatlarını devam ettirmekte herhangi bir çıkarları yoktu (Francione, 2008a, s. 253). Üstelik insan tarafından nispeten acısız bir biçimde öldürülmek, vahşi 
hayatta bir yırtıcının yol açabileceği acımasız bir ölüme kıyasla lütuf bile sayılabilirdi (Steiner, 2011, s. 2). İnsan ve hayvan arasındaki zihnî farklara yapılan bu vurguya, başka bir faydacı düşünürde, John Stuart Mill'de de (18061873) rastlamak mümkündür. Hayvanları aşağı bir türün mensupları olarak niteleyen Mill (2019, s. 31-32), insanınsa zihnî kabiliyetleri yüksek bir varlık olarak kendisine haz verecek daha çok şeye ihtiyaç duyduğunu ve acı karşısında daha kırılgan olduğunu söyler. Buna rağmen neredeyse hiçbir insanın hayvana dönüşmeye razı olmayacağını ileri süren Mill'e göre "mutsuz bir insan olmak, mutlu bir domuz olmaktan evlâdır".

'Hayvan refahı' anlayışının tarihî ve felsefî kökenlerine bu bakış, söz konusu anlayışın iki önemli karakterini gözler önüne serer. Bunlardan ilki hayvanın insandan daha düşük bir ahlâkî değere sahip olduğu düşüncesi (Francione, 2010a, s. 10), diğeri ise doğumla kazanılan haklar fikrine sıcak bakmıyor oluşudur. Zira hakkın vazifesi, ihmal edilmesi başkalarının faydasına olsa bile, menfaatin etrafını koruyucu bir duvarla örmektir. Oysa sonuç odaklı hareket eden faydacılar, eylemin sonuçlarının gerekli kıldığı hâllerde bu duvarı yıkmaya hazırdırlar. İşte suistimal edilmeye çok açik bu düşünce tarzl, hayvanın menfaatinin hemen her durumda insanın menfaati uğruna feda edilmesi sonucunu doğurmuştur. Gerçekten de hayvan kullanımlarının kahir ekseriyeti, yalnızca alışkanlık, gelenek, eğlence, rahatlık veya zevk gibi sebeplerle izah edilmekte ve bu durum hayvanların maruz kaldığı eziyetin büyük bir kısmının gereksiz olduğunu düşündürmektedir (Francione, 2008a, s. 26, 249-250). Başka bir deyişle hayvan kullanımını gerekçelendiren 'zorunluluk' kavramının içeriği keyfî olarak belirlenmekte, böylece mevcut kullanımların meşrûiyeti hayli tartışmalı hâle gelmektedir.

Günümüz dünyasında hayvanların sistematik biçimde maruz kaldıkları sömürü, 'hayvan refahı' anlayışının başarısızlığına dair iddiaları kuvvetlendiren bir nitelik taşır. Birleşmiş Milletler Gıda ve Tarım Örgütü'nün (FAO) rakamlarına göre, balıklar ve diğer deniz hayvanları hariç olmak üzere, gıda amacıyla öldürülen hayvan sayısı yılda yaklaşı 53 milyardır. Bu rakam, günde 145 milyon, saatte 6 milyon, dakikada 100 bin ve saniyede 1680 hayvana tekâbül eder (abolitionistapproach.com, 2020). Kesin bir tahminde bulunmak mümkün olmasa da her yıl bilimsel ve kozmetik deneylerde kullanılan hayvan sayısı 100 milyondan fazladır. Sadece kürkü için yılda 50 milyon civarında hayvan öldürülmektedir. Av partilerinde, hayvanat bahçelerinde, 
sirklerde, eğlence parklarında ve yarışlarda kullanılan hayvanlar da bu rakamlara eklendiğinde ortaya inanılması güç bir yekûn çıkmaktadır. Üstelik bu rakamlar buz dağının yalnızca görünen yüzünü teşkil etmekte; hayvanların bütün bu süreçlerde maruz kaldığı zulümleri perdelemektedir. Gerçekten de hayvanlar, endüstriyel hayvancilık faaliyetleri kapsamında hayatlarının neredeyse tamamın gün yüzü görmeden geçirmekte, manevra imkânını bütünüyle ortadan kaldıran daracık alanlarda hapsedilmekte, verimliliği artırmak üzere tabiatlarına aykırı biçimde beslenmekte, nakliye veya barındırma süreçlerini kolaylaştırmak üzere boynuzlarına, gagalarına ve diğer uzuvlarına ciddi zararlar verilmekte, meşrûiyeti tartışmalı deneylerde acı verici muamelelere maruz bırakılmaktadır. İktisadî rasyonalite ve sosyal refah gerekçeleriyle meşrûlaştırlan bu muamelelerin listesini uzatmak pekâlâ mümkündür.

Dolayısıyla 'hayvan refahı' anlayışının hayvanları korumakta yetersiz kaldığı düşüncesi, geçtiğimiz yüzyılın son çeyreğinden itibaren yoğun bir felsefî tartışmayı ve bunun sonucunda 'hayvan hakları' olarak anılan yeni bir yaklaşımı beraberinde getirmiştir. Bu yaklaşım esasen 'hayvanın ahlâkî dokunulmazlığı' fikrine dayanmakta, ilhamını ise Immanuel Kant'ın (1724-1804) deontolojisinden almaktadır. Kant'a göre (2018, s. 45) akıl sahibi varlıklara salt başkalarının menfaati için kullanılan araçlar olarak muamele edilemez. Çünkü bunlar kendileri birer amaç olarak vardırlar. Başka bir deyişle bu varlıklarda içkin bir değer söz konusudur; kendiliğinden bir ahlâkî değer taşırlar. İşte 'hayvan hakları' yaklaşımı, Kant'ın yalnızca insanlarla sınırladığı bu ahlâkî daireyi, hayvanları da kapsayacak biçimde genişletmiştir. Buna göre, insanî muamele çerçevesinde bile yapılsa, hayvanların insanın menfaati uğruna kullanılmaları ve öldürülmeleri ahlâken yanlıştır. Nasıl ki siyah insanlara beyazların veya kadınlara erkeklerin kaynağı olarak muamele edilemiyorsa, hayvanlara da insanların kaynağı olarak muamele edilmesi meşrû değildir. Dolayısıyla bu yaklaşım; ırkçılıkla ve cinsiyetçilikle bir tuttuğu türcülüğü açıkça mahkûm eder. Şu hâlde 'hayvan hakları' hareketinin nihaî amacı, hayvanın insanın tiranlığından topyekûn kurtarılmasıdır (Regan ve Francione, 1992, s. 40).

Aslına bakılırsa 'hayvan hakları' felsefesinin takriben son elli yıldır üstlendiği misyon, 'hayvanın insandan daha aşağı bir ahlâkî statüye sahip olduğu görüşü'ne meydan okumaktır (Garner, 2010a, s. 107). Hatırlanacağı üzere 'hayvan refahı' anlayışınca ileri sürülen bu görüş, hayvanların, insanın sahip olduğu ve onu ahlâkî cemaatin hak sahibi bir üyesi hâline getiren muhakeme 
yeteneği, otonomi, dil kullanma becerisi, benlik bilinci veya ahlâkî fâillik gibi birtakım zihnî vasıflardan yoksun olduğu anlayışına dayanıyordu (Garner, 2010b, s. 126). Buna karşı hayvan hakları felsefesi, hümanizmin zayıf karnı olarak gördüğü ahlâkî bir tutarsızlıktan yararlanarak bir dizi strateji geliştirdi. Bu tutarsızlık; insanların tamamı ahlâkî topluluğa üyelik için gerekli şartları taşımadığı hâlde, topluluğun bütün insanları kapsayacak biçimde geniş tutuluyor olmasıydı. Bahse konu şartları taşımayanlar da bu topluluğa alınacak idiyse, bu kapının neden diğer türlerin mensuplarına kapalı olduğu izah edilmeliydi. Sözgelimi demanslı bir hastadan daha akıllı olan bir köpeğin ahlâkî daire dışında bırakılmasının (Ünder, 1996, s. 168) 'türcülük' d1şında başka bir açıklaması yoktu.

Dolayısıyla hayvan hakları savunucuları, bir strateji olarak, en azından bazı hayvanların ahlâkî topluluğa üyelik için gerekli olan şartları kısmen taşıdığını iddia etmişlerdir. Buna göre meselâ insansı maymunların, sahip oldukları bazı bilişsel yetiler dolayısıyla ahlâkî topluluğa kabul edilmeleri ve böylece birtakım haklara sahip olmaları mümkündür. Ancak bu argümanla ilgili önemli bir sorun, bahse konu hayvanların topluluğa kabulünün yeni bir ahlâkî sınır çizgisi yaratması ve hayvanların büyük çoğunluğunun gerekli şartları taşımadıkları gerekçesiyle yine bu çizginin dışında kalacak olmasıdır. Dahası zihnî yetileri en gelişmiş hayvanın bile normal bir yetişkin insanla rekabet etmesi mümkün olmadığından, söz konusu vasıflar üzerine kurulan bir denklemde kaybedecek tarafin yine hayvanlar olması muhtemeldir. Hayvan hakları savunucularının diğer bir stratejisi 'marjinal vakalar' üzerinden geliştirilmiştir. Böylece ahlâki topluluğa üyelik için gereken şartları taşımayan bebekler, demanslı hastalar veya bitkisel hayat yaşayanların durumu tartışmaya açılmış; ahlâkî bakımdan tutarlı bir yaklaşımın bu insanları da hayvanlara benzer biçimde sömürmeyi ya da her ikisine de ilişmemeyi gerektirdiği ifade edilmiştir (Garner, 2010b, s. 127). Son bir strateji ise hayvanların hissetme yetisinin, 'hayvan refahı' anlayışının önerdiğinden daha yüksek bir ahlâkî statü için tek başına yeterli olduğu görüşünü içermektedir. Buna göre hayvanlar hayat veya hürriyet hakkına sahip olmayabilirler, ancak bu eşitsizliğin onların hissetme yetileriyle hiçbir ilgisi yoktur. Salt bu yetiye sahip oldukları gerçeği bile, hayvanlar üzerindeki mevcut uygulamaların pek çoğunun terk edilmesini gerektirir (Garner, 2008, s. 115-116). Şu hâlde hayvanın ahlâki statüsüne ilişkin çağdaş tartışmanın yekpare bir yapı arz etmediği 
açıktır. Takip eden kısımda bu tartışmanın en önde gelen isimlerinden Peter Singer ve Tom Regan'ın görüşlerine yer verilecektir.

\section{'Menfaatlerin Eşit Gözetilmesi' ya da 'Bir Hayatın Öznesi Olmak'}

Avustralyalı filozof Peter Singer 1975 yılında yayımlanan Hayvan Özgürleşmesi (Animal Liberation) adlı eseriyle hayvanın ahlâkî statüsüne dair tartışmalarda çığır açmış bir isimdir. Singer' in bu eserde hayvanlar lehine yaptığı müdafaa, onun kimi zaman 'hayvan hakları' hareketi içerisinde değerlendirilmesine yol açmıştır. Oysa teorisini esasen Bentham'ın 'faydacı' yaklaşımı üzerine inşa eden Singer, meseleye 'hak' perspektifinden bakmadığın, hattâ eserine bu kavramın dâhil olmasından pişmanlık duyduğunu ifade etmiştir. Aslına bakılırsa Singer, hayvanlara, acıdan kaçınmaktaki menfaatlerinin eşit gözetilmesini içeren tek bir hak tanıyor, bunun da hak kavramı kullanılmadan pekâlâ ifade edilebileceğini öne sürüyordu (Ünder, 1996, s. 170).

Singer' a göre $(2005$, s. 55-56, 240) bir varlığın herhangi bir menfaate sahip olmasının yegâne şartı, acıyı ve hazzı hissetme kabiliyetine sahip olmasıdır. Bu kabiliyete sahip varlıkların en azından acıdan kaçınmakta bir menfaatleri söz konusudur. Menfaatlerin eşit gözetilmesi prensibi, bir varlığın hissettiği ac1nın, bu varlığın ırkından, cinsiyetinden veya türünden bağımsız olarak, başka bir varlığın hissettiği benzer bir aciyla eşit gözetilmesini ifade eder. İnsanların veya hayvanların hissettiği benzer şiddetteki acılar eşit derecede kötüdür ve bu acıların önlenmesi veya mümkünse asgarî seviyeye indirilmesi gerekir. Bu acıyı dikkate almamanın veya bu acının başka bir varlığın hissettiği benzer bir acıya denk olduğunu inkâr etmenin ahlakî bakımdan hiçbir meşrû yanı yoktur. Farklı tür mensuplarının çektiği acıların kesin olarak k1yaslanması belki mümkün olmayabilir, fakat burada kesinlik şart değildir. Hayvanın menfaatinin sadece, insanın menfaatine hayvanınki kadar zarar gelmeyeceğinin kesin olduğu durumlarda gözetilmesi bile mevcut hayvan kullanımlarının pek çoğunda radikal bir dönüşümü gerekli kılacak ve çok büyük miktarda acı ortadan kaldırılacaktır.

Elbette normal yetişkin insanların zihnî kabiliyetleri, belirli şartlar altında, aynı şartlardaki hayvanlardan daha fazla ızdırap çekmelerine sebep olabilir. Meselâ parkta gezen insanların kaçırılarak üzerlerinde acı verici bir deney yapılmaya başlaması, parkta gezmeyi bir endişe kaynağı hâline getirerek deneyin yol açacağı acıya ilâve bir acı oluşturur. Öyleyse bu deneyin hayvanlar 
üzerinde tatbik edilmesi toplamda daha az aciya sebep olacaktır, zira hayvanlar, kaçırılıp üzerlerinde deney yapılacağı korkusuna kapılmazlar. Bunu söylemek, eğer bu deney kaçınılmazsa, insan yerine hayvanı tercih etmek için 'türcü olmayan bir gerekçe' ileri sürülebileceğini gösterir. Fakat burada dikkat edilmesi gereken husus; bu gerekçenin, deneylerde bebeklerin veya zihinsel engellilerin kullanılması bakımından da pekâlâ geçerli olmasıdır. Çünkü onlar da, tıpkı hayvanlar gibi, başlarına ne geleceğinden habersizdirler. Dolayısıyla hayvan deneylerini meşrûlaştırmak için bu argümanı kullananlar, bebekler veya zihinsel engellilerin de deneylerde kullanılmasına müsaade edip etmeyeceklerini kendilerine sormak durumundadırlar (Singer, 2005, s. 55).

Hayvanların acı çekmesi sorununa menfaatlerin eşit gözetilmesi prensibiyle yaklaşan Singer, konu hayvanların öldürülmesine gelince meselenin daha girift bir hâl aldığını söyler. Burada da 'insan hayatının kutsallığı' gibi türcü ve riyakâr bir anlayışın hâkim olduğunu, bu fikre sahip olanların örneğin kürtaja veya ötanaziye itiraz ederken, hayvanların öldürülmesine ses çıarmadıkların belirtir. Singer'a göre sırf Homo sapiens türüne mensup olması sebebiyle bir bebeğe hayat hakkı tanınırken hayvana tanınmıyor olması türcülügün ta kendisidir. Gelgelelim Singer bu noktada bir ayrıma giderek, sözgelimi bir köpeği öldürmenin 'normal bir yetişkin insanı' öldürmek kadar yanlış olmadığını iddia eder. Ona göre türcülügüun reddinden bütün hayatların aynı değerde olduğu anlamı çıkarılmamalıdır. Zira benlik bilincine, geleceğe yönelik hedeflere, umutlara ve plânlara sahip olma veya başkalarıyla anlamlı ilişkiler geliştirme gibi kabiliyetler, acı çektirme anlamında önem taşımıyor olsalar bile, öldürme bakımından önem taşırlar. Bu kabiliyetlere tam anlamıyla sahip bir varlığın hayatının, bunlardan yoksun bir varlığın hayatına k1yasla önemli olduğunu iddia etmek türcü bir tutum değildir. Çünkü meseleye bu zâviyeden bakıldığında, bazı hayvanların hayatının da kimi insanların hayatından daha fazla değer taşıdığına kuşku yoktur. Meselâ bir domuzun, şempanzenin veya köpeğin, bahsi geçen vasıflar bakımından, zihinsel engelli bir bebekten veya demanslı bir yaşlıdan daha ileri bir düzeyde olması mümkündür. Eğer hayat hakkı bu vasıflara isnat edilecekse, bu hayvanlara da en az bahsi geçen insanlar kadar, hattâ onlardan daha fazla hayat hakkı tanınmalıdır. Şu hâlde, herhangi bir tehlike anında insan ve hayvan hayatları 
arasında bir tercih yapmak durumunda kalındığında insan hayatının kurtarılması gerekir, fakat bu insan normal zihnî vasıflara sahip değilse, bunun tersi de pekâlâ mümkündür (Singer, 2005, s. 57-61).

Öte yandan Singer (2005, s. 308-310) hayvanların hayata ve vâroluşa dair zihnî bir devamlılıkları olmadığından dolayı, öldürülmelerinin yarattığı kaybın aynı ölçüde iyi bir hayat sürecek başka bir hayvanın dünyaya gelmesiyle telâfi edilebileceğini söyler. Dolayısıyla Singer, hayvanların zarûrî hâller d1şında gıda maksadıyla kullanılmalarına esasen karşı olmakla birlikte, tabiî ortamında iyi bir hayat sürdükten sonra acı verilmeden öldürülen bir hayvanın yenebileceğini, gıda için yalnızca bu tür hayvanları tercih eden vicdanlı insanlara saygı göstermek gerektiğini ileri sürmektedir.

Amerikalı filozof Tom Regan ise 1983 yılında kaleme aldığı ve hayvan davasının başyapıtlarından biri olarak kabul edilen The Case for Animal Rights (Hayvan Hakları Lehine Savunma) adlı eserinde, kendisini bir 'hayvan hakları savunucusu' olarak tanımlar (Regan, 2009, s. 337). Ona göre hayvanlar, insanların ahlâkî bakımdan hürmet etmekle mükellef oldukları haklara sahiptirler (Ünder, 1996, s. 176). Bu hakların tanınması, hayvanlara yönelik mevcut uygulamaların yasal düzenlemeler yoluyla iyileştirilmesini değil, topyekûn terk edilmesini gerektirir. Hayvanlara insanî biçimde muamele etmenin yeterli olmadığını iddia eden Regan (2007, s. 24); onların gıda, deney, giyim veya eğlence maksadıyla istismar edilmeleri karşısında "kafeslerin genişletilmesini değil, tamamen boşaltılmasını" talep etmektedir.

Regan'ın faydacı felsefeye ve fikirlerini bu felsefe üzerine inşa eden Singer'a itirazı vardır. Ona göre acıyı ve hazzı hissetme kabiliyetini esas alan 'duyarlıkçılık' ile toplam hazzı azamî düzeye çıkarmayı hedefleyen 'faydacılık' bir araya geldiğinde, bilhassa öldürme meselesinde kabul edilemez neticelere yol açar. Gerçekten de bu yaklaşımın bir türü olan 'eylem faydacllığı'nda toplam hazzın artması karşılığında masum bir insanın öldürülmesine dahi göz yumulması mümkündür. Faydacılığın diğer bir çeşidi olan 'kural faydacllığı'nda ise, uzun vadede zarara yol açacak bir öldürme eylemi meşrû kabul edilmeyebilir (Ünder, 1996, s. 176-177). Singer daha çok 'kural faydacılığı' ile ilişkilendirilmekle birlikte, onun bazı hayatları diğerlerinden daha değerli gören bakış açısı, kimi insanların ve hayvanların öldürülmesini meşrû hâle getirir. Regan açısından faydacılığın en büyük sorunu, canlı varlıkları hazzın ve acının hesaplanmasında birer nesne konumuna indirgemesi ve onlara içkin bir değer atfetmiyor olmasıdır (Ryan, 2019, s. 188-189). Ona göre sorulması 
gereken asıl soru "hayvanların acı çekip çekmediklerinden ziyade, bir hayatı öznesi olup olmadıklarıdır" (Masson, 2007, s. 10).

Yaklaşımını esasen Kant'ın deontolojisi üzerine kuran Regan, Kant'ın içkin ahlâkî değeri yalnızca rasyonel varlıklara, yani 'ahlâkî fâillere' atfetmesine itiraz eder. Ona göre ahlâkî dairenin kapsamı, bazı 'ahlâkî hastaları' da içerecek biçimde genişletilmelidir (Steiner, 2011, s. 3). Ahlâkî fâiller; doğru davranışı tespit etmek üzere tarafsı ahlâkî prensiplere başvurabilen ve bu doğrultuda eyleme geçmeyi veya geçmemeyi özgürce tercih edebilen bireylerdir. Bunlar söz konusu kabiliyetleri dolayısıyla eylemlerinden ahlâken sorumlu tutulurlar. Buna mukâbil kendi davranışlarını kontrol etme yetisine sahip olmayan ahlâkî hastalar, eylemlerinden dolayı herhangi bir sorumluluk taşımazlar. Regan bu ahlâkî hastaları bazı nitelikleri itibariyle iki kategoriye ayırır. Bu kategorilerden ilkinde acıyı ve hazzı hissetmek dışında başka zihnî kabiliyetleri olmayan kimi hayvanlar yer alır. Regan'ın esas ilgi alanına giren ikinci kategorideki hayvanlar ise; "inançlara, arzulara, algılama ve anımsama yeteneğine, bir amaç istikametinde eylem başlatma becerisine, kendi gelecekleri de dâhil olmak üzere bir gelecek duygusuna, zaman içerisinde gelişen psikofizikî bir kimliğe, duygusal bir hayata, tercih yapma özerkliğine ve bireysel bir refaha" sahip olan varlıklardır (Regan, 2005, s. 31-35). İşte Regan'a göre bir yaşın üzerindeki bütün normal zihinli memeliler, sahip oldukları bu niteliklerle 'bir hayatın öznesi olma' kriterini sağlayan bireylerdir (Des Jardins, 2006, s. 238). Böylece bu kriter ahlâkî fâillerle bazı ahlâkî hastalar arasında müşterek bir payda teşkil etmekte (Regan, 2003, s. 93) ve onlara içkin bir değer kazandırmaktadır. Dolayısıyla "saygın muamele görme hakkı da dâhil olmak üzere birtakım haklara sahip olan" (Regan, 2007, s. 91) bu bireylere salt başkalarının aracı olarak muamele edilmesi ahlâken meşrû değildir.

Görünen o ki Regan'ın yaklaşımı, bir hayatın öznesi olmaları dolayısıyla insanla hayvan arasında ahlâkî statü bakımından bir eşitlik tesis eder. Hayvanların başkalarına yararı olup olmamasından bağımsız olarak kendiliğinden bir değer taşıdıkları düşüncesi, onların da tıpkı insanlarınki gibi bazı haklara sahip olmalarını gerektirir. Bu ahlâkî haklar, insanları, hayvanları öldürmekten, onlara zarar vermekten ve özgürlüklerini kısitlamaktan menetmeyi amaçlayan, diğer bir ifadeyle hayvanların hayatını, bedenini ve özgürlüğünü insanın müdahalesinden korumayı öngören haklardır (Regan, 2007, s. 63).

Dolayısıyla Regan'ın 'hayvanın ahlâkî statüsü' meselesinde hayli radikal bir yaklaşıma sahip olduğuna hiç şüphe yoktur. Fakat buna rağmen Regan, 
içkin değer kavramını bazı zihnî niteliklerle ilişkilendirdiği ithamına maruz kalmaktadır. Bunun sebebi Regan'ın bir 'fevkalâde durum senaryosu' karşısında aldığı tavırdır. Senaryoya göre bir kazadan sağ çıkan dört yetişkin normal insan ve bir normal köpek, yalnızca dört kişiyi taşıyabilecek bir cankurtaran sandalına çıkmayı başarmışlardır. Ancak sandalın kapasitesi yeterli olmadığından, bunlardan birinin denize atılması gerekmektedir. Regan'a göre, insan gelecekte hayatın tatmini bakımından köpeğe kıyasla çok daha büyük fırsatlara sahip olacağından, ahlâken en uygun davranış köpeğin denize atılması olur. Zira ölüm köpek için her ne kadar bir kötülük olsa da, insan için nitel bakımdan daha büyük bir kayıp ve daha büyük bir kötülük anlamına gelecektir. Hattâ Regan söz konusu tercihin bir insanla bir milyon köpek arasında yapılması durumunda bile sonucun değişmeyeceğini; köpeklerin feda edilmesi gerektiğini ileri sürer. Regan'ın bu vakadaki yaklaşımının, insana hayvan karşısında ayrıcalık tanıyan geleneksel ahlâkî hiyerarşiye rücu etmek anlamına geldiği ifade edilmektedir (Francione, 2008a, s. 243; Steiner, 2011, s. 4).

\section{Hayvan Haklarına Radikal Bir Yaklaşım: Francione'nin Abolisyonizmi}

Hayvanın ahlâkî statüsüne ilişkin çağdaş tartışmanın en önde gelen isimlerinden biri olan Amerikalı filozof Gary L. Francione, hayvanların yegâne kurtuluş yolunun mülk statülerinin sona erdirilmesinden ve her türlü hayvan kullanımının topyekûn terk edilmesinden geçtiğini iddia eden 'abolisyonist' yaklaşımın başlıca temsilcisidir. Francione bir yandan Singer gibi hazzı ve acıyı hissetme kabiliyetinin ahlâkî statü için gerekli yegâne kriter olduğunu ileri sürerken, diğer yandan da Regan gibi, hayvanların içkin bir ahlâkî değer taşıdıkları fikrine sahiptir. Fakat bununla birlikte zihnî gelişmişlik düzeyinin ahlâkî statü değerlendirmelerinde hiçbir yerinin olmaması gerektiğini söyleyen Francione, ahlâkî hiyerarşilerin tümden reddini içeren deontolojik bir pozisyonun savunuculuğunu yapar (Steiner, 2011, s. 4-5). Dolayısıyla Francione'nin bazı açlardan Singer ve Regan'dan ayrıldığını ve onlara kıyasla daha radikal bir tavır aldığını söylemek mümkündür.

Sözgelimi Francione'ye göre (2008a, s. 254), Singer'ın genellikle hayvan hakları davasının öncüsü olarak kabul ediliyor olması büyük bir ironiden ibarettir. Zira ona göre Singer'ın, hayvanın hissetme kabiliyeti, benlik bilinci ve hayatını sürdürmekteki menfaati arasındaki ilişkilere dair bazı fikirleri son 
derece problemlidir. Öncelikle Singer, tuhaf bir biçimde, hissedebilen bir varlığın ölümden herhangi bir zarar görmediğini iddia etmektedir. Oysaki hissetme kabiliyeti kendi içinde (per se) bir amaç değil, ona sahip olan varlığın, hayatını tehlikeye atan durumları saptamasını ve bunlardan kaçınarak hayatta kalmasını mümkün kılan bir araçtır. Dolayısıyla hissetme kabiliyetini haiz bütün varlıkların, yaşadıkları hayatın yalnızca niteliğinde değil, niceliğinde de menfaatleri söz konusudur. Francione'ye göre (2010a, s. 16) bu gerçeği inkâr etmek, gözleri olan varlıkların görmeyi sürdürmekte bir menfaatleri olmadığını veya kör olmaktan zarar görmediklerini iddia etmek kadar gülünçtür. İkinci olarak Francione (2008a, s. 261-269), Singer'ın hayvanlarda benlik bilinci olmadığına dair görüşünü de hayli sorunlu bulur. Çünkü hissetme yetisine sahip bir varlık bilinç sahibi olduğundan, o varlığın benlik bilincine sahip olmadığını iddia etmek, onun acıyı hissedebildiğini fakat bu ac1nın kendi başına geldiğini kavrayamadığını veya buna aldırış etmediğini ileri sürmek anlamına gelir. Bu iddiayı 'safsata' olarak niteleyen Francione' ye göre, bilinç sahibi olan her varlık ahlâkî bakımdan bir benlik bilincine de sahiptir. Singer'ın yaklaşımında insanın hayatını sürdürmekte bir menfaati söz konusuyken, hayvanın benlik bilincinden yoksun olduğu gerekçesiyle bu menfaatten mahrum bırakılması, eşit gözetilme prensibinin adilâne biçimde nasıl uygulanabileceğine dair soru işaretleri yaratmaktadır. Kaldı ki bu yaklaşım benlik bilinci olmayan bazı insanlara da, yaşamakta menfaatleri olmadığı gerekçesiyle birer kaynak olarak muamele edilebileceği sonucuna götürür. Nitekim Singer'a göre acısız bir biçimde gerçekleştirilmek şartıyla ileri düzeyde zekâ geriliği olan insanların organ nakli amacıyla öldürülmelerinde herhangi bir sakınca yoktur. Netice itibariyle Singer'ın yaklaşımının, hayvanlara daha insanî bir muamele imkânı sağlamakla birlikte, onların normal insanlara reva görülmeyen biçimlerde kullanılmalarına engel olmadığı açıktır.

Öte yandan Francione, Regan'ın hayvanların kurumsal istismarına son verilmesini vâdeden 'haklar' görüşüne katılmakla birlikte, onunla da fikir ayr1lığına düştüğü bazı noktalara dikkat çeker. Öncelikle Francione, hak tanınan hayvanların 'bir hayatın öznesi' olarak tanımlananlarla sınırlandırılmasına itiraz eder. Ona göre bu kriteri tam olarak karşılayamayan kimi hayvanların da, hissetme kabiliyetine sahip olmak şartıyla, acı çekmemekte menfaatleri söz konusudur. Benzer biçimde Francione (2008a, s. 41-42), Regan'ın insanla hayvan arasındaki zihnî farkları gerekçe göstererek 'cankurtaran sandalı senaryosu' karşısında aldığı tavrı eleştirir ve bu tarz olağanüstü durumlarda 
hayvandan ziyade insanın kurtarılmasın gerektiren herhangi bir prensibin söz konusu olmadığını söyler. Ona göre bu gibi durumlarda insanın tercih edilmesi elbette mümkündür, fakat bu tercih, insanın hayvana kıyasla kurtarılma hakkına daha fazla sahip olmasından değil, hayvandan ziyade insanla daha doğrudan bir özdeşlik kurulması sebebiyle yapılabilir. Dolayısıyla tersi bir durumda hayvanın kurtarılması da pekâlâ mümkündür (Steiner, 2011, s. 6). Francione (2008a, s. 42) kendi yaklaşımının Regan'ınkinin aksine hayvanların hukukî mal statüsüne odaklandığını, hayvanların bu statüleri devam ettiği müddetçe ahlâkî bakımdan önemi olmayan 'şeyler' muamelesi göreceklerini, dolayısıyla hayvanların 'mal veya kaynak olarak muamele görmeme hakkı' gibi tek bir haklarının olduğunu ifade eder. Ona göre doğrudan 'eşit gözetilme prensibi'nden türetilmesi mümkün olan bu hak, Regan'in temel aldığı girift haklar kuramını gerektirmemektedir.

\section{Francione'nin Hayvanın Mülk Statüsüne Dair Görüşleri}

Francione (2008b, s. 25, 37-38), insanların hayvanlar hakkında söyledikleriyle gerçekte onlara reva gördükleri muamele arasında derin bir tutarsızlık olduğunu söylemektedir. Gerçekten de hayvanların ahlâkî bakımdan önemli menfaatleri olduğu ve bunların ciddiye alınması gerektiği sıklıkla dile getirilmesine rağmen, bu menfaatlerin önemsiz birtakım gerekçelerle sürekli olarak göz ardı edilmesi söz konusudur. Hayvanlar karşısında sergilenen bu tavrı 'ahlâkî bir şizofreni' olarak tanımlayan Francione, bu şizofreniyi hayvanların mülk statüsüyle ilişkilendirmektedir. Mülk statüleri sebebiyle hayvanlar, sahipliğe konu olan ve onlara verilmesi uygun görülen değerden başka hiçbir değeri bulunmayan metalardan ibarettir. Bu bakımdan, hayvanları koruduğu düşünülen kanunlar esasen mülk sahibinin hayvan üzerindeki haklarını düzenleme işlevi görür. Mülk sahibinin hayvanını kazanç elde etmek için kullanması, onunla ilgili sözleşmeler yapması, onu teminat olarak göstermesi, miras bırakması, bağışlaması ve öldürmesi, bu kanunlar aracılığıyla birtakım kurallara bağlanır.

Hayvanın mülk statüsü Batı kültüründe iki sebepten ötürü büyük önem taşır. Bu sebeplerden ilki mülkiyet hakkının insanın sahip olduğu en önemli haklardan biri olarak görülmesi, diğeri ise mülkiyet kavramının, hayvanların Tanrı tarafından bahşedilmiş kaynaklar olduğu düşüncesiyle ilişkilendirilmiş olmasıdır. Mülkiyet haklarının başlıca mimarı John Locke'a (1632-1704) 
dayanan bu düşünceye göre, Tanrı insana hayvanlar üzerinde hâkimiyet bahşettiğinden dolayı, hayvanların sahip olunabilecek diğer kaynaklardan veya nesnelerden hiçbir farkı yoktur (Francione, 2008a, s. 130-133). Hâl böyle olunca, hayvanın mülk statüsü, hayvan refahı kanunlarının öngördüğü 'menfaatlerin eşit gözetilmesi' prensibini anlamsız kılar. Çünkü bir kefesinde 'mülk sahibinin haklarla koruma altına alınmış olan menfaatlerinin', diğer kefesinde ise 'mülk statüsündeki hayvanin menfaatlerinin' bulunduğu dengesi bozuk bir terazinin her defasında kimden yana ağır basacağı aşikârdır (Francione, 1996a, s. 127). Bu dengesizliği gidermek üzere dişarıdan yapılan müdahaleler ise, bireysel özgürlüğ̈ ihlâl edeceği, iktisadî etkinliğe zarar vereceği veya toplumsal refahta azalışa sebep olacağı gerekçesiyle her zaman şüpheyle karşılanmaktadır (Francione, 1996b, s. 47).

Hayvan refahı kanunlarının bu menfaatler terazisinde hiçbir zaman anlamlı bir denge sağlayamayacak olmasının birkaç önemli sebebi vardır. $\mathrm{Bu}$ sebeplerden ilki, hayvanların ızdırabına ve ölümüne yol açan hayvanclık, avcllık, balıkçlık ve biyomedikal araştırmalar gibi geleneksel birçok faaliyet için bu kanunlarda açık muafiyetler tanınmış olmasıdır. İkincisi, kanunların bu muafiyetleri açıkça sağlamadığı durumlarda mahkemeler devreye girmekte ve en acı verici muameleleri bile, hayvanı insanın kullanımına hazır hâle getirmek için yapılan alışılagelmiş uygulamalar oldukları gerekçesiyle kanun kapsamı dışında değerlendirmektedir. Üçüncü olarak bu kanunlar hayvana acı veren eylemin fâil tarafından suç işleme kastıyla veya kötü niyetle yapılmış olması şartını aramaktadır. Oysa söz konusu eylem alışılagelmiş bir hayvan kullanımı esnasında gerçekleşmişse, burada suç işleme kastının veya kötü niyetin varlığını ispat etmek zorlaşmaktadır. Son olarak çoğu refah kanununun içerdiği ceza hükümleri son derece yetersizdir ve ihlâller kolluk görevlilerince pek ciddiye alınmamaktadır. Mülkiyet haklarına müdahale anlamına gelebileceği gerekçesiyle en bariz ihlâl durumlarında bile kanunların uygulanmasinda isteksiz davranılabilmektedir (Francione, 1995, s. 134). Genel olarak değerlendirildiğinde, hayvan refahı kanunlarının hayvanlar üzerindeki mevcut uygulamaları türlü gerekçelerle meşrulaştırmak gibi bir işleve sahip olduğunu söylemek mümkündür.

Bütün bu tespitlerden hareketle Francione (2008a, s. 28-29), hayvan menfaatlerini ciddiye almanın yegâne yolunun, eşit gözetilme prensibini hayvanlara da uygulamak ve onlara insanın malı olarak muamele görmeme hakkını 
tanımak olduğunu ifade eder. Hayvanlar, tıpkı insanlar gibi hissetme kabiliyetini haiz ve acı çekmemekte menfaati olan varlıklardır. Nasıl ki insanların başkalarının malı olmamaktaki menfaati 'hak' denen bir mekanizmayla korunuyorsa, bu hakkın kapsamı hayvanları da ihâta edecek şekilde genişletilmelidir. Francione'ye göre (2005, s. 24) makûl ve tutarlı bir hayvan hakları teorisinin odaklanması gereken tek hak budur. Hayvanların bu hakka sahip olması, üzerlerindeki kurumsallaşmış sömürü mekanizmalarının birtakım reformlarla iyileştirilmesini veya kurala bağlanmasını değil, topyekûn ortadan kaldırılmasını gerektirir (Francione, 2008b, s. 25). Bunun anlamı; hayvanların yiyecek, giyecek, eğlence veya deney gibi amaçlarla kullanımının, evcil hayvan üretiminin ve vahşi hayvan katlinin tamamiyla terk edilmesidir (Francione, 2008a, s. 35; Francione, 2010, s. 1).

\section{Francione'nin Hayvan Hakları Hareketine Dair Görüşleri}

Francione' nin hayvanların mülk statüsü dişında üzerinde önemle durduğu diğer bir husus 'hayvan hakları teorisi' ile 'hayvan hakları hareketi olarak bilinen toplumsal fenomen' arasında ortaya çıkan ayrışmadır. Francione' ye göre modern 'hayvan hakları hareketi', hayvan hakları teorisini tutarlı bir toplumsal değişim stratejisine tercüme etmekte başarısız olmuştur. Gerçekten de bu hareket, haklara ilişkin terminolojiyi, hayvan ızdırabını azalttığı düşünülen her türden düzenlemeyi tanımlamak için kullanmaya başlamıştır. Sözgelimi 'hayvan refahı' anlayışının bir örneği olarak deney hayvanlarının kafeslerinin bir nebze büyütülmesi, bu hareket tarafından 'hayvan hakları'nı gerçekleştiren bir uygulama olarak alkışlanabilmiştir. Dolayısıyla modern hayvan hakları hareketi, hayvan haklarını ulaşılması gereken ideal bir amaç olarak kabul etmekle birlikte, bu haklara ilişkin felsefî doktrini ütopik olduğu gerekçesiyle reddetmekte ve söz konusu ideal amaca ulaşmanın yolunun hayvan refahı düzenlemelerinden geçtiğini iddia etmektedir. Francione, kısa vadede hayvan refahı reformlarını, uzun vadede ise hayvan hakları nihaî amacını benimseyen bu hibrit pozisyonu 'yeni refahçlık' olarak adlandırmaktadır. Yeni refahçılar, örneğin şimdinin geniş ve temiz kafesleriyle yarının boş kafesleri arasında bir nedensellik ilişkisi olduğuna inanmaktadırlar. Nihayetinde hayvan hakları hareketi, haklar terminolojisini kullanmasına ve uzun vadede kurumsallaşmış sömürünün kaldırılması hedefine rağmen öyle bir strateji takip eder ki, bunu en azından bazı sömürü biçimlerini sorun etmeyenlerin strateji ve 
söylemlerinden ayırt etmek zordur (Francione, 1998, s. 45). Bu bağlamda Francione (1996a, s. 221); Ulusal Viviseksiyon * Karşıtları Cemiyeti (National AntiVivisection Society/NAVS), Amerikan Viviseksiyon Karşıtlan Cemiyeti (American Anti-Vivisection Society/AAVS), Hayvan Haklar Yanlısı Feministler (Feminists for Animal Rights/FAR), Amerikan Insaniyet Cemiyeti (Humane Society of the United States/HSUS) ve hattâ kendisini genellikle 'radikal' olarak tanımlayan Hayvanlara Etik Muamele İçin Mücadele Edenler Derneği (People for the Ethical Treatment of Animals/PETA) gibi kuruluşların, hak kavramını felsefî anlamıyla değil yalnızca bir retorik olarak kullandıklarını ve hayvan hakları teorisinin somut bir kılavuz olamayacağını düşündüklerini söyler.

Francione'ye göre (Regan ve Francione, 1992, s. 40-41) 'hayvan refahı reformları' yoluyla 'hayvan hakları' amacına ulaşılabileceği görüşü, ahlâkî, pratik ve kavramsal birtakım sebeplerden ötürü hatalıdır. Ahlâkî bakımdan bu görüş, geleceğe ilişkin hayli mesnetsiz ve mantık dışı bir spekülasyona dayanmaktadır. Sözgelimi hayvanların kullanıldığı bilimsel araştırmaların daha insanî hâle getirilmesinin, gelecekte bu araştırmalarda hayvan kullanılmayacağını garanti eden hiçbir yanı yoktur. Daha nazikçe bir tecavüzün veya daha insanî bir kölelik düzeninin, nihayetinde tecavüzü ve köleliği ortadan kaldıracağı düşüncesi külliyen yanlıştır. Pratik açıdan bakıldığında da bunun böyle olduğu görülmüştür. Meselâ ABD'de hayvanların bilimsel araştırmalarda kullanılmasına ilişkin yasal değişiklikler büyük bir beklenti yaratmış, ancak sonrasında hayvan davasına gönül verenlerin umutları suya düşmüştür. Çünkü bu değişiklikler söz konusu araştırmalara son vermediği gibi, Kongre'nin dahli sayesinde araştırmacılara büyük bir meşrûiyet de sağlamıştır. Bu açıdan bakıldığında hayvan refahı düzenlemelerinin aslında hayvan hakları hareketinin başarısını sekteye uğrattığı görülür. Zira bu düzenlemeler özellikle geniş halk kitlelerindeki vicdanî rahatsızlığı gidermekte; insanların gönül rahatlı̆̆ıla hayvan tüketimini ve kullanımını sürdürmesine sebep olmaktadır. Kavramsal açıdan bakıldığında ise insanların hak sahibi bireyler olduğu, hayvanlarınsa mülk olarak kabul edildiği bir düzende hayvanların her zaman kaybeden tarafta olacaklarına hiç şüphe yoktur.

\footnotetext{
* 'Hayvan teşrihi' veya 'dirikesim' olarak da anılan viviseksiyon, hayvanların bilimsel amaçlar için cerrahî metotlar kullanılmak sûretiyle parçalarına ayrılması işlemidir.
} 
Dolayısıyla Francione (Akt. Elise, 2013, s. 22-24) hayvan kullanımınin hukukî reformlar vasıtasıyla düzenlenmesi üzerine inşa edilen her türlü stratejiyi problemli bulmaktadır. Ona göre bir uygulama ahlâken yanlışsa, o uygulamada reform yapılmasına yönelik kampanya yürütmenin hiçbir anlamı yoktur. Üstelik bu tarz reformların ardındaki birincil motivasyonun hayvan refahına ilişkin endişelerden ziyade kâr güdüsü olduğu unutulmamalıdır. Gerçekten de bu reformların sağladığı iyileşmenin hayvanların iktisadî açıdan en etkin biçimde sömürülmesine imkân sağlayan bir koruma düzeyini aşması mümkün değildir. Sözgelimi ABD'deki İnsanî Kesim Yasası'nda yer alan 'hayvanın ayaklarından zincire asılmadan önce sersemletilmesine ilişkin hüküm', aslında hayvanın iyiliğinden ziyade, çırpınan hayvanın hem mezbaha iş̧ilerine hem de kendi vücuduna zarar vermesini engellemeyi ve böylece üretim kaybının önüne geçmeyi amaçlıyordu. Dolayısıyla Francione'ye göre bu reformlar, bunları riyakâr bir biçimde zafer olarak sunan bazı 'hayvan koruma cemiyetleri'nin, destekçilerinden sağladıkları bağışları sürdürmeleri dişında hiçbir işe yaramamaktadır.

Bu bağlamda Francione'nin hayvan hakları aktivistlerine yönelik bir dizi strateji önerisi vardır. İk olarak aktivistler, reform kampanyaları veya tek bir soruna odaklanan kampanyalar yerine, sözgelimi 'kozmetik veya ürün testlerinde hayvan kullanımı' gibi belirli hayvan sömürülerinin ortadan kaldırılmasını hedefleyen kampanyalara yönelmelidirler. Çünkü tek bir soruna odaklanan kampanyalar genellikle sömürünün bir biçiminin diğeriyle ikâme edilmesine sebep olmaktadır. Örneğin hayvan barınaklarının terk edilmiş ev hayvanlarını araştırma kurumlarına devretme uygulamasına karşı yürütülen kampanya, bu hayvanlar yerine salt bu amaç için üretilen başka hayvanların kullanılmasına yol açmıştır (Francione, 2018, s. 10-11). İkinci olarak bu kampanyalarda veganizmin ahlâkî bir mecburiyet olarak mutlaka teşvik edilmesi gerekir. Bu konuda son derece hassas olunması ve vejetaryenizm tuzağına düşülmemesi gerektiğine dikkat çeken Francione'ye göre, et yeme ile diğer hayvansal ürünlerin tüketimi arasında ahlâkî bakımdan bir fark yoktur. Nitekim mandıra hayvanları et için kullanılanlardan genellikle daha uzun süre sömürülmekte, en az onlar kadar kötü muamele görmekte ve nihayetinde aynı mezbahanın yolunu tutmaktadırlar. Dolayısıyla Francione (2010b, s. 12) biftek yemekle süt içmek arasında yalnızca hayvanın çektiği acı temelinde bir tercih yapmak zorunda kalsa bifteği tercih edeceğini belirtmektedir. Son olarak Francione (Akt. Elise, 2013, s. 37) aktivistlerin şiddetten ve mülkleri tahrip 
etmekten uzak durmaları gerektiğini, zira vandalizmi çağrıştıran bu tarz eylemlerin zaman ve kaynak israfından başka bir şey olmadığını söyler. Bu eylemler hayvan ürünlerine olan talebi etkilemediği gibi, aktivistlerin terörist veya suçlu gibi algılanmasına sebep olarak davaya zarar vermektedir. Ona göre hayvan sömürüsünün terk edilmesi, ancak yaratıcı bir vegan eğitiminin hayvan ürünlerine olan talebi azaltmasıyla mümkün olacaktır.

\section{Francione'nin Abolisyonizmine Yönelik Eleştiriler}

Francione' nin gerek hayvanın mülk statüsüne gerekse de hayvan hakları hareketinin mevcut stratejisine ilişkin hayli radikal sayılabilecek bu görüşleri pek çok düşünürün eleştirisine maruz kalmıştır. Bu düşünürlerin başında gelen Robert Garner (2010a, s. 103) hayvan hakları yaklaşımını büyük ölçüde ikna edici bulmakla birlikte, bu yaklaşımın özel bir türünü teşkil eden abolisyonizme yönelik itirazı olduğunu belirtir. Ona göre abolisyonizm, hayvan kullanımının terk edilmesinin ahlâken makûl ve siyaseten mümkün olduğu iddiasında yanılmaktadır.

Garner (2010a, s. 116, 128) ilk olarak, hayvan meselesi üzerine kafa yoran düşünürler arasında insan hayatının hayvanınkinden daha değerli olduğuna dair genel bir mutabakat olduğunu söyler. Ona göre de ölüm, süregelen bir hayatın sunabileceği değerli imkânlardan mahrum bırakarak insana büyük bir zarar verir. Buna mukâbil hayvanlar, hayata dair plânlar yapmak ve bunları takip etmek şöyle dursun, hayatta kalma kavramını bile anlamaktan acizdirler. Buradan hareketle Garner, Francione' nin aksine, otonom olmamaları sebebiyle hayvanların hayat ve hürriyet haklarının söz konusu olamayacağını, sahip olabilecekleri tek hakkın acı çekmeme hakkı olduğunu söyler. Dolayısıyla Garner'a göre bu haklarına saygı duyulduğu sürece hayvanların mülkiyete konu olmaları ahlâken bir sorun teşkil etmez. Başka bir deyişle, herhangi bir acı verilmediği müddetçe hayvan üzerindeki zilyetliğin ve bunun beraberinde getirdiği 'bulundurma', 'kullanma' ve 'nakletme' eylemlerinin hayvanın çıkarını ihlâl etmesi söz konusu değildir. Dahası Garner'a göre (2002, s. 79-80) hayvanın mülk statüsünün ortadan kaldırılmasının her derde deva olacağı düşüncesi yanlıştır. Nitekim vahşi hayvanlar özel mülkiyete konu olmamalarına rağmen acımasız bir biçimde sömürülmeye devam etmektedir. Kaldı ki bir hakkın tanınmış olması, o hakkın lâyıkıyla tatbik edileceği anlamına gelmez. Sözgelimi insan haklarının varlığı insan sömürüsünü ortadan 
kaldırmaya yetmemektedir. Dolayısıyla hukukî statü etrafında dönen tartışmanın, hukukî yapının içinde işliyor olduğu sosyo-politik konteksti gözden kaçırma riski taşıdığını söyleyen Garner'a göre (2008, s. 117-118) hayvanların mülk statüsü bir sebep değil, onlara verilen düşük değerin bir sonucudur. Şu hâlde esas üzerinde durulması gereken mesele, hayvanlara yönelik sosyal tutumlardaki ârızadır. Bu tutumlarda meydana gelecek değişiklikler, hayvanlara yasal statü tanımayı yahut haklar bahşetmeyi bizatihi lüzumsuz hâle getirecektir.

Abolisyonist yaklaşıma yönelik en büyük eleştirilerden biri, bu yaklaş1mın bilhassa 'hayvan refahı' düzenlemeleri karşısındaki sekter tavrının hayvan hareketinde ciddi bir bölünmeye yol açıyor olmasıdır. Abolisyonistlerin sahip olduğu 'ya hep ya hiç' mantığının hem hayvan hareketine zarar verdiğini hem de hayvanlara hiçbir faydasının dokunmadığını söyleyen Newkirk (1992, s. 44-45), kendi başindan geçen bir hadiseyi bu duruma örnek olarak gösterir. Newkirk'ün anlattı̆ına göre sığır endüstrisi lobisi, kesilmek üzere olan hayvanlara su verilmesi zorunluluğunun iptali için hükümete baskı yapmaya başlamıştır. Bunun sebebi suyun maliyetli, hayvanların da zaten ölecek olmasıdır. Hükümet ise sığır endüstrisinin baskısına yenik düşmek üzeredir. Bunun üzerine hayvan hareketi mensupları bir imza kampanyası başlatmış ve dilekçelerden bir kısmını da imzalamaları için abolisyonist bir topluluğa ulaştırmıştır. Topluluk, dilekçeleri imzalamadığı gibi, yanına bir de not iliştirerek gerisin geriye göndermiştir. Notta topluluğun hayvan kesimine ahlâkî olarak karşı olduğu, dolayısıyla bu olaya müdahil olmak istemedikleri yazılıdır. Dili damağına yapışmış hâlde üç gün boyunca kesilmeyi bekleyen zavallı sığırlara bir yudum suyu çok gören bu tavrı anlamakta zorlandığını söyleyen Newkirk, felsefenin hayvanları haklara kavuşturmadan önceki uzun yıllar boyunca pekâlâ onların acılarını dindirmeyi de deneyebileceğini ifade etmektedir. Newkirk'e göre abolisyonistlerin bu tavrı, mutabık olunan meselelerde kolektif iş yapma imkânını ortadan kaldırmaktadır.

Garner da (1998, s. 86-88) bu konuda Newkirk'le aynı fikirdedir. Ona göre de bu bölünmeyi ortadan kaldırarak ittifak hâlinde hareket etmek pazarlık gücünü artıracak, hayvanların durumunun iyileştirilmesi adına hükümetlerden daha fazla taviz koparılmasını sağlayacaktır. Öte yandan Garner (2013, s. 89) mevcut hayvan refahı yasalarının ve reformlarının kifayetsizliği konusunda Francione'ye katılmakla birlikte, bu tarz düzenlemelerin hayvanlara yönelik muameleler üzerinde hiçbir tesiri olmadığı iddiasının tartışmaya açık 
olduğunu söylemektedir. Bu düzenlemelerin genellikle 'lüzumsuz eziyet etmeme' prensibini temel aldığını belirten Garner, 'lüzumsuz' kavramının içeriğinin ise son otuz yılda hayli değiştiğine dikkat çekmektedir. Bu gelişmede etkili olan hususlar; hayvanların muhtelif acılarına ilişkin farkındalı̆̆ın artması, kültürel normların değişmesi ve bilhassa deneylerde alternatif metotların kullanılmasını mümkün kılan teknolojik ilerlemelerdir. Dolayısıyla eskiden normal kabul edilen kürk giymek, kozmetikleri hayvanlar üzerinde test etmek, kümes hayvanlarının gagasını kesmek, süt danalarını kafesli sandıklara koymak, domuzları ayrı bölmelere koyarak bağlamak veya tavuklar için batarya kafesler kullanmak gibi birçok uygulama, artık lüzumsuz görülerek ya terk edilmekte veya ahlâkî bakımdan sorgulanmaktadır. Dolayısıyla Garner (1996, s. 5), hayvan refahı düzenlemelerine Francione gibi yekten karşı çıkmak yerine, bu düzenlemeleri elverişli olup olmadıkları üzerinden değerlendirmenin daha uygun bir tavır olduğunu söylemektedir. Ona göre deneylerde daha az hayvan kullanılması daha çok kullanılmasından her hâlükârda evlâdır.

Francione' nin hayvan hakları hareketinin düzenlediği kampanyaların zaman ve kaynak israfına sebep olduğu düşüncesi de eleştirilerden nasibini almaktadır. Sözgelimi Friedrich (2011), hayvan refahı yasalarının ileri düzeyde olduğu ülkelerin ayn zamanda en fazla hayvan hakları aktivisti barındıran ülkeler olduğuna dikkat çekmektedir. Ona göre bu kampanyalar, Francione'nin iddia ettiğinin aksine, $\mathrm{ABD}^{\prime}$ de hayvan etine olan talep üzerinde önemli bir negatif etki yaratmaktadır. Ayn şekilde Phelps de (2008) aktivistlerin bilhassa endüstriyel çiftliklerde yapılan fenalıkları ifşa ettiğini, böylece hayvanların da acıya duyarlı ve refahları önemsenmesi gereken varlıklar olduğu konusunda halkı bilinçlendirdiğini söyler. Üstelik yürütülen bu kampanyalar, insanları bir 'hayvan hakları ütopyası' uğruna hayvanların çektiği ızdıraba sırt çevirmenin utancından kurtarmaktadır. Phelps, hayvan hareketinin amaçları konusunda farklı yaklaşımlara sahip olunabileceğini fakat araçlarla ilgili pragmatik bir tavra ihtiyaç duyulduğunu belirtmektedir. Ona göre hayvanlar insanlardan alabilecekleri her türlü yardımı istisnasız bir biçimde almalıdırlar. Benzer biçimde DeCoux da (2009, s. 41), hayvan hakları aktivistlerinin kullandığı stratejik araçların abolisyonistlerinkinden daha etkili olduğu düşüncesindedir. Ona göre abolisyonistler hayvan ızdırabından bahis açıldığında genellikle 'lüzumsuz eziyet etmeme' prensibinin tutarsızl1- 
ğından veya hayvan refahı yasalarının başarısızlığından dem vurmaya eğilimlidirler. Bunu yaparken de hayvan ızdırabına ilişkin ayrıntılara girmekten ziyade filozofların görüşlerine başvururlar. Buna karşın hayvan hakları aktivistleri, hayvanların mezbahalarda maruz kaldığı vahşeti, görüntüler, fotoğraflar ve anlatılar yoluyla gayet çarpıcı bir biçimde tasvir ederler ve duygusal reaksiyonu seferber etmekte çok daha başarılıdırlar.

Garner (2010, s. 147-148) abolisyonistlerin ferdî alışkanlıkların değiştirilmesini amaçlayan ve bilhassa 'vegan ol' sloganında anlamını bulan ahlâkî mücadele stratejisinin, hukukî reformu amaçlayan politik kampanyalarla desteklenmedikçe başarısızlığa mahkûm olacağını iddia etmektedir. Abolisyonistlerin bu stratejisi, veganizmin erdemleri hususunda insanlarm eninde sonunda ikna edilebileceğini varsaymakta, yani menfaatler karşısında fikirlere öncelik tanımaktadır. Oysa siyasî arenada kamu politikası çıktılarının belirleyicileri fikirlerden ziyade menfaatlerdir ve insanların kendilerine menfaat vâdetmeyen herhangi bir çağrıya kulak vermeleri zordur. Dahası araştırmalar insanla hayvan arasındaki menfaat çatışması şiddetlendikçe hayvanlara yönelik ahlâkî ilginin azaldığını da ortaya koymaktadır. Şu hâlde söz konusu ahlâkî mücadelenin hayli sınırlı bir strateji olduğu ortadadır (Garner, 2010, s. 125-126). Abolisyonist bir strateji üzerine düşünürken, dünyada hiçbir ülkenin tıbbî araştırmalarda veya besin kaynağı olarak hayvan kullanımını yasaklamadığı, bu faaliyetlerle ilişkili endüstrilerin son derece güçlü olduğu, çoğu insanın et tüketmeye ve hayvanlar üzerinde test edilen ilaçlardan yararlanmaya devam ettiği hatırda tutulmalıdır (Garner, 2008, s. 116). Bu verili durum göz önüne alındığında, insanlarla hayvanların ahlâkî statü bakımından eşitliği fikrinin toplumda kabul görmesini beklemek iyimser bir tavır olur. Abolisyonist yaklaşımın, soyut prensipleri somut gerçekler ışığında yorumlamaya ve ayakları yere basan bir strateji oluşturmaya ihtiyacı vardır (Garner, 2010, s. 144).

\section{Sonuç}

20. yüzyılın son çeyreği hayvanın ahlâkî statüsünü konu alan hayli zengin bir felsefî tartışmanın doğuşuna şahitlik etmiştir. Bu tartışmanın en radikal isimlerinden biri ise hiç şüphesiz Gary L. Francione'dir. Francione'nin 'abolisyonizm' olarak tesmiye olunan yaklaşımı, hayvanın mülk statüsünün sona erdirilmesini ve her türlü hayvan kullanımının topyekûn terk edilmesini ifade 
etmektedir. Aslına bakilırsa Francione hayvanlara yalnızca 'mülk olarak muamele görmeme' hakkını tanımakta, bu hakkı ise birbiriyle yakından ilişkili üç sacayağı üzerine oturtmaktadır. Bunlar; 'çıkarların eşit biçimde gözetilmesi', 'hayvanın mülk statüsünün sona erdirilmesi' ve 'hayvan refahı reformlarına karşı itiraz'dır. Francione' yi Peter Singer ve Tom Regan gibi diğer önemli düşünürlerden ayıran temel husus, 'çikarların eşit gözetilmesi' prensibi karşısında gösterdiği tavizsiz sadâkatidir. Gerçekten de ona göre insanla hayvan arasındaki zihnî gelişmişlik farkları, hayvanın çıkarının göz ardı edilmesinin mazereti olarak asla ileri sürülemez. Dolayısıyla Francione'nin ahlâkî bakımdan mutlak bir eşitlik peşinde olduğu aşikârdır. 'Hayvanın mülk statüsünün sona erdirilmesi' ise onun yaklaşımında hayatî bir öneme sahiptir. Francione hayvanlara reva görülen zulmün temelinde bu statünün yattığını, hayvanların birer 'mal' olarak kabulünün onların çıkarlarını âdilâne biçimde gözetmeyi imkânsız hâle getirdiğini söyler. Francione'nin 'hayvan refahı reformlarına karşı itirazı' da işte tam bu noktada devreye girer. Ona göre hayvanların mülk statüsü ortadan kaldırılmadığı sürece 'hayvan refahı' adı altında yapılan her türlü reform mevcut sistemin tahkim edilmesine yol açmaktadır. Friedrich'in (2011) ifade ettiği gibi, abolisyonistlere göre bu tarz islah edici metotlar hastalığı tedavi etmez, temdit eder. Başka bir deyişle kölelere nazik davranılması köleliği ortadan kaldırmaz, bilakis onun devamına yol açar. Dolayısıyla Francione 'hayvan hakları hareketi'nin refah reformları peşinde koşmasına karşı çıkmakta ve bunun hayvan hakları davasına faydadan çok zarar getirdiğini ileri sürmektedir.

Francione' nin bu sekter tavrı en az iki bakımdan sorun arz etmektedir. Bu sorunlardan ilki, hayvanı ahlâkî bakımdan insanla eşit statüde gören ve böylece her türlü hayvan kullanımının terk edilmesini salık veren yaklaşımdan kaynaklanmaktadır. Bu yaklaşımın reel dünyada herhangi bir karşılığının olduğunu iddia etmek oldukça zordur. Çünkü gerçekçi bir gözle bakıldığında insanların kahir ekseriyetinin ne hayvanla eşit bir statüye ne de mevcut hayvan kullanımlarını terk etmeye razı olmaları mümkün görünmemektedir. Hele ki bu ideallerin 'veganizm' merkezli ikna programlarıyla gerçekleşeceğini varsaymak hayli iyimser bir tavırdır. Dolayısıyla abolisyonist yaklaşımın felsefe ile hakikat arasındaki makası kapatacak ve insana daha fazla temas edecek bir stratejiye ihtiyacı olduğu açıtır. İkinci sorun ise abolisyonizmin hayvan refahı reformlarına yönelik tavrından kaynaklanmaktadır. Mevcut durumda hayvan refahı düzenlemelerinin yetersizliği aşikâr olmakla birlikte, 
bu düzenlemelerin refah reformları aracıllğıyla iyileştirilemeyeceğini varsaymak özcü bir yaklaşımdır. Dahası refah reformlarına 'hayvan hakları' davasına zarar verdiği gerekçesiyle karşı çıkmak, muhayyel bir 'hayvan hakları' geleceği uğruna, vârolan hayvan ızdırabını umursamamak anlamına gelir. Böyle bir stratejinin ne hayvanlara ne de onların acılarına temas eden hiçbir yanı yoktur. Herhâlde hayvan meselesi karşısında alınması gereken en sağlıklı tavır, hayvanın ahlâkî bakımdan insandan daha aşağı bir düzeyde yer aldığını kabul etmek ve onun acıya duyarlı bir varlık olduğu gerçeğini ciddiye almaktır. 


\section{EXTENDED ABSTRACT}

\section{The Moral Status of the Animal in the Western Philosophy: An Assessment on Francione's Abolitionism \\ Hakan Olgun \\ Bilecik Şeyh Edebali University}

The question of how human relations with animals should be considered within a moral framework has been one of the most ancient topics of discussion in Western philosophy. However, it is obvious that this debate has often resulted against the animals throughout the history. For example, the ancient Greek world focused on man as the measure of everything. The Story of Creation adopted by Christianity from the Old Testament clearly presented animals to the benefit of Man, and the idea of Enlightenment went further and claimed that animals were machines having no ability to feel pain. The animal was considered to be an object having no immanent moral value could be abused for the sake of man's purposes. The idea of having a direct moral obligation for the animal was not accepted. The idea that animals are deprived of certain abilities and qualities usually reserved for humans such as the ability to question, the ability to use language skills, self-awareness, or moral agency, has created an insurmountable obstacle to their inclusion in the moral community.

The period of 19th century was a time when the understanding of animals began to change, especially with the influence of 'pragmatist' philosophers. The 'humane treatment principle' considered as the credo of this period represented that animals, as beings capable of feeling, had at least a vested interest in not suffering. Thus, it imposed a direct moral obligation for animals forbidding unnecessary cruelty to them. Moreover, this new understanding was not only a moral principle; it was also stated in anti-persecution laws enacted in the United States and Britain at the time, and in many other countries later on. All these developments form the basis of the understanding of 'animal welfare' widely accepted in today's world and inspire such laws. 
However, these developments being in favor of the animals have failed to alleviate animal suffering and the discussion continued on this issue. The reason for this failure is to be examined in the principle of 'unnecessary cruelty', inherent in the understanding of 'animal welfare'. Yet, it is possible to conclude that some treatment involving torture is 'necessary' from the opponents of the concept of 'unnecessary torture'. In practice, it has been concluded that if the human benefit from such treatment is greater than the animal's suffering, then the suffering is necessary. There is no doubt how open such an assessment is to manipulation and arbitrariness. In almost every case where the interests of man and the interests of the animal are in conflict, the first one is preferred, and the cruel treatment to animals has created a very wide repertoire.

The fact that the understanding of animal welfare was partially successful cleared the way for a deep philosophical debate as of 1970s. The philosophers who led the debate rejected the idea that animals should be excluded from the moral community due to the fact that they were deprived of the mental abilities. For instance, the fact that even humanoid apes with certain mental abilities were excluded from the moral community, while babies or patients with dementia were not excluded, and even the idea of their use in painful experiments was found to be appalling, was a clear indication of the inconsistency of the current acceptance. The boundaries of the moral borders should have been extended as to include animals, according to some of the philosophers naming this arbitrary approach as 'speciesism' for the moral boundaries. These philosophers offered a different set of solutions. For instance, Peter Singer argued that the case for 'animal liberation' could be acquired 'through equal consideration of the interests of animals not to suffer'; while Tom Regan suggested that the 'subject of a life' should be considered in terms of determining the boundaries of the moral community.

Gary L. Francione who offered one of the most radical examples of such ideas was one of the leading representatives of the 'abolitionist' approach claiming that the only way to save animals was through the termination of their property status and the abandonment of all forms of animal use. On one hand, Francione similar to Singer stated that the ability to feel pleasure and pain was the sole criterion for moral status whereas he had the idea that animals had an inherent moral value like Regan. However, noting that the mental 
development level should have no place in moral status assessments, Francione advocates a deontological position including unequivocal rejection of moral hierarchies. Thus, it is possible to emphasize that Francione was not on the same side with Singer and Regan and adopted a more radical attitude.

Francione addressed that there was a discrepancy between what humans said about the animals and the way they actually treated them. Although the fact that animals have morally important interests and that they should be taken seriously are emphasized, these interests are ignored based on various justifications. Highlighting that this attitude towards animals can be described as a 'moral schizophrenia', Francione associates this schizophrenia with the property status of animals. Recognition of the rights of animals not to be treated as a property requires their institutionalized exploitation mechanisms to be completely abolished, not to be reformed or to be enforced. In other words, there should be a complete cessation for the use of animals for purposes such as food, clothing, entertainment or experiments, for the production of pets and the slaughter of wild animals.

Another issue Francione highlighted other than the property status of animals was the separation between the 'animal rights theory' and the social phenomenon known as the 'animal rights movement'. According to Francione, the modern 'animal rights movement' has failed to interpret animal rights theory into a coherent strategy of social change. This movement started to be used as the terminology related to the rights describing any kind of regulation believed to reduce animal suffering. Therefore, the modern animal rights movement accepting animal rights as an ideal aim to be fulfilled rejects the philosophical doctrine of these rights since it is utopian and claims that the way to achieve this ideal goal is to regulate animal welfare. Francione names this hybrid position 'new welfarism' embracing animal welfare reforms in the short term and the ultimate goal of animal rights in the long term. New welfarists believe that there is a relationship of causality between the wide and clean cages of today and the empty cages of the tomorrow. As a conclusion, despite its use of rights terminology and its long-term goal of abolishing institutionalized exploitation, the animal rights movement follows a strategy which is difficult to distinguish at least some forms of exploitation from the strategies and discourses of those who do not mind. Accordingly, the strategy to follow is to decrease the demand for animal products through educational programs focusing on veganism and being free from violence, rather than supporting 
reformist campaigns. Francione's radical ideas on the abolition of animal property status and the current strategy of the animal rights movement have been accused of being 'extreme' and 'far from reality by many philosophers '.

\section{Kaynakça / References}

Animal Rights The Abolitionist Approach (t.y). Hayvan haklarl: Abolisyonist yaklaşım. 09.02.2020 tarihinde abolitionistapproach.com adresinden erişilmiştir.

Arslan, A. (2016). Felsefeye giriş. Ankara: BB101.

Bentham, J. (2017). An introduction to the principles of morals and legislation. 02.01.2020 tarihinde earlymoderntexts.com/assets/pdfs/bentham1780.pdf adresinden erişilmiştir.

DeCoux, E. L. (2009). Speaking for the modern prometheus: The significance of animal suffering to the abolition movement. Animal Law, 16(1), 9-64.

Des Jardins, J. R. (2006). Çevre etiği: Çevre felsefesine giriş. (Çev. R. Keleş). Ankara: İmge Yayınları.

Elise, T. (2013). Anti-capitalism and abolitionism. K. Socha ve S. Blum (Eds.). Confronting animal exploitation: Grassroots essays on liberation and veganism içinde (s.22-43). Jefferson, North Carolina and London: McFarland \& Company, Inc., Publishers.

Francione, G. L. (1995). Animals, property, and the law. Philadelphia: Temple University Press.

Francione, G. L. (1996a). Rain without thunder: The ideology of the animal rights movement. Philadelphia: Temple University Press.

Francione, G. L. (1996b). Animal rights: An incremental approach. R. Garner (Ed.). Animal rights: The changing debate içinde (s.42-60). London: Macmillan Press.

Francione, G. L. (1998). Animal rights and new welfarism. M. Bekoff (Ed.). Encyclopedia of animal rights and animal welfare içinde (s.45). Westport: Greenwood Press.

Francione, G. L. (2005). One right for all. New Scientist, 24.

Francione, G. L. (2008a). Hayvan haklarına giriş: Çocuğunuz mu köpeğiniz mi?. (Çev. R. Akman ve E. Gen). İstanbul: İletişim Yayınları.

Francione, G. L. (2008b). Animals as persons: Essays on the abolition of animal exploitation. New York: Columbia University Press. 
Francione, G. L. (2010a). The abolition of animal exploitation. G. L. Francione and R. Garner. The animal rights debate: Abolition or regulation içinde (s.1-102). New York: Columbia University Press.

Francione, G. L. (2010b). Vegetarianism first? The conventional wisdom and why it's wrong. The Vegan, 12-13.

Francione, G. L. (2018). Reflections on Tom Regan and the animal rights movement that once was. Between the Species, 21(1), 1-41.

Friedrich, B. (2011, 21 Şubat). Getting from A to Z: Why animal activists should support incremental reforms to help animals. Huffington Post.

Garner, R. (1996). Part I: Animal rights, moral theory and political strategy. R. Garner (Ed.). Animal rights: The changing debate içinde (s. 1-6). London: Macmillan Press.

Garner, R. (1998). Political animals: Animal protection politics in Britain and the United States. Hampshire and London: Macmillan Press.

Garner, R. (2002). Political ideology and the legal status of animals. Animal Law, 8(77), 77-91.

Garner, R. (2008). The politics of animal rights. British Politics, 3, 110-119.

Garner, R. (2010a). A defence of a broad animal protectionism. G. L. Francione and R. Garner. The animal rights debate: Abolition or regulation içinde (s. 103-174). New York: Columbia University Press.

Garner, R. (2010b, Ocak-Mart). Animals ethics and public policy. The Political Quarterly, 81(1), 123-130.

Garner, R. (2013). Theory of justice for animals: Animal rights in a nonideal world. New York: Oxford University Press.

Kant, I. (2018). Ahlâk metafiziğinin temellendirilmesi. (Çev. I. Kuçuradi). Ankara: Türkiye Felsefe Kurumu.

Masson, J. M. (2007). Önsöz. Tom Regan. Kafesler boşalsın: Hayvan haklarıyla yüzleşmek. (Çev. S. Çağlayan). içinde (s.9-12). İstanbul: İletişim Yayınları.

Mill, J. S. (2019). Faydacılık. (Çev. G. Murteza). İstanbul: Pinhan Yayınları.

Newkirk, I. (1992). Total victory, like checkmate, cannot be achieved in one move. The Animals' Agenda, 12(1), 43-45.

Phelps, N. (2008). One-track activism: Animals pay the price. 11.02.2020 tarihinde abolitionistapproach.com adresinden erişilmiştir.

Regan, T. (1998). Animal rights. M. Bekoff (Ed.). Encyclopedia of animal rights and animal welfare içinde (s.42-43). Westport: Greenwood Press.

Regan, T. (2003). Animal rights, human wrongs: An introduction to moral philosophy. Oxford: Rowman \& Littlefield. 
Regan, T. (2005). Hayvan hakları için temel argümanlar. (Çev. E. Gen). Birikim, 195, 31-36.

Regan, T. (2007). Kafesler boşalsın: Hayvan haklarıyla yüzleşmek. (Çev. S. Çağlayan). İstanbul: İletişim Yayınları.

Regan, T. (2009). The case for animal rights. J. E. White (Ed.). Contemporary moral problems içinde (s.336-344). Belmont CA: Thomson Wadsworth.

Regan, T. ve Francione, G. L. (1992). A movement's means create its ends. The Animals' Agenda, 12(1), 40-43.

Ryan, D. (2019). Hayvan kuramı: Eleştirel bir giriş. (Çev. A. Alkan). İstanbul: İletişim Yayınları.

Singer, P. (1996). Animal liberation. R. Garner (Ed.). Animal rights: The changing debate içinde (s. 7-18). London: Macmillan Press.

Singer, P. (2005). Hayvan özgürleşmesi. (Çev. H. Doğan). İstanbul: Ayrınt Yayınları.

Steiner, G. (2005). Anthropocentrism and its discontents: The moral status of animals in the history of western philosophy. Pittsburgh: University of Pittsburgh Press.

Steiner, G. (2011, 23 Aralık). The differences between Singer, Regan and Francione. The Abolitionist, 1-7.

Ünder, H. (1996). Çeore felsefesi: Etik ve metafizik görüşler. Ankara: Doruk Yayınları.

\section{Kaynakça Bilgisi / Citation Information}

Olgun, H. (2020). Batı felsefesinde hayvanın ahlâkî statüsü: Francione'nin abolisyonizmi üzerine bir değerlendirme. OPUS-Uluslararası Toplum Araştırmaları Dergisi, 15(25), 3916-3948. DOI: 10.26466/opus.720047 